\title{
Paweł Romaniuk
}

Uniwersytet Warmińsko-Mazurski, Olsztyn

pawel.romaniuk@uwm.edu.pl

ORCID: https://orcid.org/0000-0002-7217-956X

\section{Wybrane prawnoadministracyjne aspekty realizacji zasady jawności w sferze funkcjonowania administracji publicznej}

http://dx.doi.org/10.12775.SIT.2021.036

\section{Wprowadzenie}

Zasada jawności w sferze aktywności administracji publicznej, a także jawność informacji na temat funkcjonowania państwa i reprezentujących je funkcjonariuszy publicznych są jednymi $z$ fundamentalnych kryteriów rozwoju każdego demokratycznego państwa prawa. Zgodnie $z$ założeniami art. 4 Konstytucji Rzeczypospolitej Polskiej z dnia 2 kwietnia 1997 r.: „Władza zwierzchnia w Rzeczypospolitej Polskiej należy do Narodu, który sprawuje ją

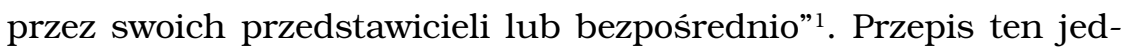
noznacznie akcentuje ważną rolę, jaką wypełnia suweren ${ }^{2}$. Według Wiesława Kraluka przyjęcie w Konstytucji Rzeczypospolitej Polskiej postanowienia, że władza należy do Narodu, stanowi zaakcentowa-

${ }^{1}$ Zob. art. 4 Konstytucji Rzeczypospolitej Polskiej z dnia 2 kwietnia 1997 r. (Dz.U. z 1997 r. Nr 78, poz. 483 ze zm.), dalej: Konstytucja RP.

${ }^{2}$ O ważnej roli suwerena pisze np. M. Gulczyński, Zasada zwierzchnictwa narodu, w: Zasady podstawowe polskiej Konstytucji, red. W. Sokolewicz, Warszawa 1998, s. 107-116. 
nie „[...] permanentnego charakteru owego zwierzchnictwa Narodu. Suwerenność Narodu tym samym trwa cały czas i nie wyczerpuje się w całości w demokratycznym akcie wyborczym, co można by wywodzić $z$ ewentualnego zapisu o pochodzeniu władzy od Narodu"3. Ujęcie takie jednoznacznie argumentuje konieczność udziału obywateli w kreowaniu kontroli społecznej w zakresie realizacji zadań publicznych przez aparat państwowy.

Ponadto traktowana w ten sposób jawność, jako dobro wspólne będące własnością wszystkich obywateli, musi być identyfikowana jako konsekwencja odpowiedzialnej pracy wszystkich organów i instytucji publicznych oraz reprezentujących je urzędników. Wszyscy powinni zatem być zainteresowani tym, aby państwo prawa funkcjonowało prawidłowo, praworządnie, szanując przyjęte wolności i prawa wszystkich, którzy znajdują się pod jego zwierzchnictwem, mając jednocześnie prawo dostępu do informacji publicznej. Przedmiotowy artykuł dotyczy charakterystyki prawnej wybranych prawnoadministracyjnych założeń zasady jawności w obszarze funkcjonowania i rozwoju administracji publicznej.

\section{Usytuowanie zasady jawności w systemie konstytucyjnym}

Należy zaznaczyć, że w materii przepisów Konstytucji Rzeczypospolitej Polskiej z dnia 2 kwietnia 1997 r. można odnaleźć zasadę jawności. W doktrynie prawa administracyjnego prezentowane są różne stanowiska. Jednak w orzecznictwie można spotkać się z konstrukcją prawną, przybierającą postać tzw. zasady prawa do informacji publicznej, która bezpośrednio pochodzi $z$ dyspozycji zawartej w art. 61 Konstytucji RP ${ }^{4}$. W orzecznictwie sądów administracyjnych można zaobserwować wyraźną tendencję, która dotyczy zwiększenia zakresu stosowania prawa dostępu do informacji pu-

${ }^{3}$ W. Kraluk, O rozumieniu i regulacji normatywnej demokracji bezpośredniej $w$ nowej Konstytucji, „Gdańskie Studia Prawnicze” 1998, nr 3, s. 24.

4 Szerzej zob. wyrok NSA z dnia 10 lutego 2016 r., I OSK 1321/15, Lex nr 1984335. 
blicznej. Zauważalny wpływ na ukształtowanie takiego orzecznictwa wywarło wejście w życie ustawy o dostępie do informacji publicznej5. Ustawa ta ewidentnie zwiększyła katalog podmiotów, które zostały uprawnione do uzyskania informacji publicznej, a także wyodrębniła katalog podmiotów zobowiązanych do jej udzielenia. Rozstrzygnięcia sądów administracyjnych wyznaczyły kierunek rozumienia i identyfikowania działań w zakresie wglądu do dokumentów urzędowych wraz z możliwością zapoznania się $z$ materiałami, które stanowią pomoc przy sporządzeniu takich dokumentów ${ }^{6}$.

Obowiązek udostępniania obywatelom informacji publicznej wynika nie tylko $z$ przepisów prawa krajowego. Prawa te wynikają m.in. $\mathrm{z}$ art. 10 Konwencji o ochronie praw człowieka i podstawowych wolności, która określana jest jako Europejska konwencja praw człowieka ${ }^{7}$, oraz z przepisów art. 19 Międzynarodowego paktu praw obywatelskich i politycznych ${ }^{8}$. Umowy te są częścią polskiego wewnętrznego i spójnego porządku prawnego, natomiast ich ustalenia stosuje się bezpośrednio, co wynika $z$ regulacji art. 91 Konstytucji RP.

$\mathrm{Z}$ zasadą jawności silnie koresponduje wspomniana zasada dostępu do informacji publicznej. Regulacje te nie stanowią expressis verbis o prawie do informacji publicznej, ale wyznaczają zasady prawa do informacji o działalności organów władzy publicznej, a także osób pełniących funkcje publiczne. Można jednak dostrzec, że wyznaczenie norm tego prawa, jako prawa do informacji publicznej, jest silnie powiązane $z$ postanowieniami jakże ważnej ustawy o dostępie do informacji publicznej ${ }^{9}$. Ponadto zagwarantowane we

${ }^{5}$ Ustawa $z$ dnia 6 września 2001 r. o dostępie do informacji publicznej (tekst jednolity: Dz.U. z 2020 r. poz. 2176), dalej: u.d.i.p.

${ }^{6}$ M. Mucha, Obowiazki administracji publicznej $w$ sferze dostępu do informacji, Wrocław 2002, s. 44-47.

7 Konwencja o ochronie praw człowieka i podstawowych wolności sporządzona w Rzymie dnia 4 listopada 1950 r. (Dz.U. z 1993 r. Nr 61, poz. 284 ze zm.).

8 Międzynarodowy pakt praw obywatelskich i politycznych z dnia 23 kwietnia 1977 r. (Dz.U. z 1977 r. Nr 38, poz. 167).

9 M. Jabłoński, Udostępnienie informacji publicznej $w$ formie wglądu do dokumentów, Wrocław 2013, s. 30-31. 
354 Pawet Romaniuk

wspomnianym przepisie art. 61 Konstytucji RP prawo dostępu do informacji publicznej stanowi bez wątpienia jeden $z$ ważniejszych prawnych warunków rozwoju społeczeństwa obywatelskiego. Społeczeństwo takie charakteryzuje się przede wszystkim dużą świadomością i obecnością obywateli w życiu publicznym. Obywatele mogą otrzymać informacje $z$ zakresu działalności organów władzy publicznej oraz osób pełniących funkcje publiczne. Prawo to dotyczy również uzyskiwania informacji o działalności organów samorządu gospodarczego czy zawodowego, a także o sposobie gospodarowania środkami publicznymi lub majątkiem Skarbu Państwa.

Analizując znaczenie prawa dostępu do informacji publicznej, jako elementu wdrażania sfery jawności obserwowanej w polskiej przestrzeni prawnej, należy wskazać, że na podstawie założeń zapisów Konstytucji RP prawo to zostało uznane za prawo podmiotowe. Taki sposób postrzegania prawa przyczynia się do rozwoju świadomości w zakresie dostępu do informacji publicznej ${ }^{10}$. Należy przy tym zaakcentować, że w doktrynie jako prawa podmiotowe definiuje się takie prawa, mogące być przyznane w dużej mierze na drodze sądowej, które po stronie jednostki wywołują określone roszczenia związane $z$ procesem ich wdrażania ${ }^{11}$.

Funkcjonowanie organów władzy publicznej oparte jest na zasadzie jawności. Zasada ta łączy się $z$ uprawnieniem wstępu na posiedzenia organów kolegialnych, które pochodzą $z$ wyborów powszechnych $^{12}$, jak również dotyczy jawności postępowania sądowego, $\mathrm{w}$ tym publicznego ogłaszania wyroków ${ }^{13}$. $Z$ istoty konstytucyjnych regulacji jasno wynika, że każde ograniczenie dotyczące jawności musi znajdować swoją odpowiednią regulację prawną, co jest równoznaczne $z$ tym, że przyjęta prawnie zasada jawności jest standardem, tajemnica natomiast może w takim przypadku być wyjątkiem.

${ }^{10}$ Zob. A. Surówka, Prawo dostępu do informacji publicznej $w$ orzecznictwie sądów administracyjnych, „Przegląd Prawa Konstytucyjnego” 2013, nr 3(15), s. 150 .

11 B. Banaszak, Prawo konstytucyjne, Warszawa 2008, s. 457-459.

12 Zob. art. 61 ust. 2 w związku $z$ art. 113 Konstytucji RP.

13 Art. 45 ust. 2 Konstytucji RP. 
Innym ważnym konstytucyjnym prawem, które jest ściśle powiązane $\mathrm{z}$ obowiązkiem informacyjnym jednostki, jest przepis art. 74 ust. 3 Konstytucji RP. Regulacja ta zapewnia każdemu prawo do informacji w zakresie poziomu ochrony środowiska. Prawa te ze swej natury pozwalają na realizację wolności pozyskiwania i rozpowszechniania informacji, zapewnionej w art. 54 ust. 1 Konstytucji $\mathrm{RP}^{14}$. Aby jednak obywatele mogli sprawować swoją władzę, wskazaną w przepisie art. 4 ust. 2 Konstytucji RP, muszą posiadać pełną informację o stanie państwa. W sytuacji, kiedy obywatele pozbawieni są prawdziwych, wiarygodnych, rzetelnych i sprawdzonych informacji dotyczących spraw publicznych, w żaden sposób nie mogą odpowiedzialnie i z najlepszą wiedzą podejmować ważnych decyzji. Mogą być również pozbawieni prawa decydowania o sposobie obsadzenia organów państwowych. Stąd mocno akcentowane konstytucyjne prawo dostępu do informacji publicznej zostało przyznane przede wszystkim osobom, które w sposób rzeczywisty mogą wpływać na sytuację w państwie. Uwzględniając powyższe argumenty, wskazujące na konstytucyjne przesłanki ściśle połączone $z$ jawnością sfery publicznej, będącej gwarantem demokratycznych praw, można stwierdzić, że jest to filar niezbędny do funkcjonowania i rozwoju państwa prawa.

\section{Kształtowanie zasady jawności w sferze publicznej}

Trzeba wskazać, że suweren, który sprawuje zwierzchnią władzę, powinien posiadać dostateczną wiedzę i aktualne informacje na temat funkcjonowania administracji publicznej. Taka wiedza jest niezbędna, aby móc w pełni odpowiedzialnie wykonywać jakże potrzebną kontrolę społeczną nad działalnością jego przedstawicieli. Wiedza ta jest również niezbędna do podejmowania świadomych decyzji w zakresie wyboru tych przedstawicieli, którzy przez określony czas reprezentują sprawy swoich wyborców. Doktryna

14 Podejście takie reprezentuje J. Sadomski, w: Konstytucja RP, t. 1: Komentarz do art. 1-86, red. M. Safjan, L. Bosek, Warszawa 2016, Legalis. 
w obszarze prawa administracyjnego wskazuje jednak, że jawne działanie władz publicznych buduje rzeczywisty aspekt legitymizacji takich władz ${ }^{15}$. Także zasady obejmujące wolności i prawa jednostki, związane $z$ prawem do pozyskania informacji publicznej, oraz wolność pozyskiwania i przekazywania informacji stanowią kluczowy fundament prawidłowego rozwoju społeczeństwa obywatelskiego. Wspomniane społeczeństwo obywatelskie traktowane jest jako społeczeństwo aktywnych, świadomych i zaangażowanych w sprawy publiczne obywateli. Taka postawa oczywiście cieszy, tym bardziej że procesów do oceny społecznej z każdym rokiem jest coraz więcej. Społeczeństwo takie ma prawny i faktyczny dostęp do informacji publicznej, co jest niezbędnym wymogiem realnej partycypacji społecznej ${ }^{16}$.

$\mathrm{Na}$ rozbudowaną sferę jawności życia publicznego składa się kilka istotnych aspektów. Znaczenie pojęcia jawności należy identyfikować $z$ obecnością takiego stanu faktycznego, w ramach którego wszystkie obiektywne informacje są jak najbardziej dostępne. Tworzą one jednocześnie płaszczyznę, za pomocą której istnieje możliwość otrzymania takich informacji, kreującą przy tym obraz prawdziwej rzeczywistości. Jawność w odniesieniu do życia publicznego oznacza najczęściej swobodny dostęp zainteresowanego do każdej informacji, czyli danych o działalności istniejącego aparatu publicznego, a także reprezentujących go w różnych instytucjach przedstawicieli. Należy również przyjąć, że jawność musi być traktowana jako możliwość pozyskania informacji w zakresie wszelkich przejawów aktywności, lub oczywiście jej braku, w sferze funkcjonujących instytucji publicznych oraz reprezentujących je osób. Jednak zgodnie $z$ art. 5 ust. 1 ustawy o dostępie do informacji publicznej prawo do informacji publicznej podlega ograniczeniu w zakresie i na zasadach określonych w przepisach o ochronie

15 S. Osowski, B. Wilk, Jawność jako wyznacznik legitymizacji władz publicznych, w: Studia nad współczesnymi ruchami społecznymi, red. A. Wojtaszak, Szczecin 2014, s. 49-50.

16 Por. M. Jabłoński, op.cit., s. 15-17. 
informacji niejawnych oraz o ochronie innych tajemnic ustawowo chronionych $^{17}$.

Jawność życia publicznego w odniesieniu do struktur państwa oraz jego funkcjonariuszy staje się potrzebnym instrumentem, wykorzystywanym przez każdego obywatela do kontroli legalności i rzetelności funkcjonowania tych wszystkich podmiotów i osób, które wchodzą w skład rozbudowanej tzw. sfery władztwa publicznego. Musi przy tym wzrastać świadomość urzędników w zakresie obowiązku udostępnienia informacji publicznej. W przypadku braku właściwej reakcji ze strony funkcjonariuszy publicznych ustawodawca wskazał konsekwencje nieudostępnienia informacji publicznej, obejmujące zastosowanie grzywny, kary ograniczenia wolności albo pozbawienia wolności do roku ${ }^{18}$. W tym obszarze swoje uwagi przedstawia Teresa Górzyńska, kształtując ciekawe stanowisko, że każdy funkcjonariusz publiczny powinien jak najszybciej zrozumieć fakt, iż rozwój całej administracji publicznej powinien być oparty przede wszystkim na dobrej komunikacji obywatela $z$ konkretnym urzędem. Muszą także pojawić się odpowiednie argumenty, przemawiające za koniecznością zagwarantowania równego i sprawiedliwego dostępu każdemu obywatelowi do informacji publicznej ${ }^{19}$. Stąd taka forma komunikacji musi spełniać kilka ważnych warunków:

- musi być widoczny napływ informacji, wykorzystujący nowoczesne narzędzia informatyczne;

- sfera jawności życia publicznego powinna gwarantować efektywne i realne uczestnictwo obywateli w procesach decyzyjnych;

- należy ograniczyć obszar przekazywanych informacji do zakresu, który bezpośrednio wynika $z$ konkretnego wniosku w sprawie dostępu do informacji publicznej.

Realizacja założeń kontrolnych życia publicznego najczęściej skierowana jest na ocenę funkcjonowania wszystkich organów

17 Szerzej: art. 5 ust. 1-2 u.d.i.p.

18 Art. 23 u.d.i.p.

19 Zob. T. Górzyńska, Zasada jawności $w$ administracji, „Państwo i Prawo” 1998, nr 6, s. 14. 
administracji publicznej, co oczywiście nie jest zadaniem prostym. Ocena ta koncentruje się na pozyskiwaniu różnych informacji dotyczących osób, które pełnią funkcje publiczne. W takim ujęciu określenie „osoba publiczna” jest jednak szersze pojęciowo i podmiotowo. Pojęcie to dotyczy także osób, które pełnią w życiu publicznym ważne role $z$ punktu widzenia budowania różnorodnych postaw i opinii ludzi. Ciekawą analizę przedstawia Trybunał Konstytucyjny, który uznaje, że „[...] pojęcie osoby pełniącej funkcje publiczne jest [...] ściśle związane $z$ konstytucyjnym ujęciem prawa $z$ art. 61 ust. 1, a więc nie może budzić wątpliwości, że chodzi tu o osoby, które związane są formalnymi więzami $z$ instytucją publiczną (organem władzy publicznej)" ${ }^{20}$. Jednak w opinii Trybunału nie jest możliwe dokładne określenie, czy i w jakich okolicznościach osoba realizująca różne zadania w organach administracji publicznej będzie mogła być uznawana za sprawującą funkcję publiczną. Rozumienie takie znajduje bowiem swoje uzasadnienie $\mathrm{w}$ fakcie, że nie każda osoba publiczna może być osobą pełniącą funkcje publiczne. Dlatego niezbędnym warunkiem w takich sytuacjach, według opinii Trybunału Konstytucyjnego, staje się wskazanie, czy pełnienie funkcji publicznej wiąże się $z$ realizacją konkretnych zadań w danym urzędzie, w ramach wyodrębnionej struktury władzy publicznej lub na innym stanowisku, mającym charakter stanowiska kierowniczego.

Słusznie argumentował Trybunał Konstytucyjny, że cechą każdego demokratycznego państwa jest to, że osoba publiczna „[...] nie może, w imię jakości debaty publicznej, manipulować post factum swoimi wypowiedziami. A jeżeli nawet, to opinia publiczna ma prawo to wiedzieć, jako o ważnym elemencie wpływającym na postrzeganie autora takich zmiennych wypowiedzi. [...] Obywatele oczekują, że politycy będą osobami, które mają odwagę podejmowania mądrych decyzji w trudnych sytuacjach. Jeżeli polityk nie jest pewny tego, co mówi, nie jest pewny słów, których używa w sytuacji publicznej, udzielając informacji, to może to być sygnał dla opinii

${ }^{20}$ Zob. wyrok TK z dnia 20 marca 2006 r., K 17/05. 
publicznej, że może sobie nie radzić w trudnej sytuacji. Opinia publiczna ma prawo do wiedzy na ten temat" ${ }^{21}$.

Nie pojawia się przy tym wątpliwość, że jawność i przejrzystość kształtowania się mechanizmów, towarzyszących działaniom państwa i jego funkcjonariuszy publicznych, stają się kluczem do prowadzenia przez każdego zainteresowanego obywatela kontroli i oceny w zakresie prawidłowości działań instytucji publicznych. Stąd tak ważne znaczenie ma uwierzytelnienie w Konstytucji RP nie tylko prawa dostępu do informacji publicznej (art. 61 Konstytucji RP), ale również wszelkich wzajemnych uprawnień oraz funkcjonujących zasad ${ }^{22}$.

\section{Uwarunkowania jawności procesu stanowienia prawa}

Przedmiotowa jawność procesu stanowienia prawa jest konstytucyjnie zagwarantowana jawnością posiedzeń Sejmu Rzeczypospolitej Polskiej i Senatu Rzeczypospolitej Polskiej ${ }^{23}$. Proces stanowienia prawa, podobnie jak powyższe działania, również został objęty regulacjami prawnymi, których cechą wspólną jest zapewnienie całkowitej jawności, transparentności oraz przejrzystości omawianych mechanizmów. Dotyczy to aktywności nie tylko obejmującej sferę prowadzenia szeroko rozumianej działalności lobbingowej24, ale także tej, która jest ściśle związana ze wskazaną powyżej jawnością posiedzeń Sejmu i Senatu, jak również rozwijających się mechanizmów rozpowszechniania informacji, z zaakcentowaniem istotnych założeń rzetelności prasowych ${ }^{25}$.

21 Zdanie odrębne przedstawił sędzia TK do wyroku TK z dnia 29 września 2008 r., SK 52/05.

22 M. Jabłoński, op.cit., s. 27-31.

23 Art. 113 w związku $z$ art. 124 Konstytucji RP.

24 Zob. Ustawa $z$ dnia 7 lipca 2005 r. o działalności lobbingowej w procesie stanowienia prawa (tekst jednolity: Dz.U. z 2017 r. poz. 248).

25 Por. M. Bernaczyk, Konstytucyjne prawo do informacji o działalności posłów i senatorów a zakres podmiotowy ustawy o dostępie do informacji publicznej, „Przegląd Sejmowy” 2012, nr 3, s. 57-59. 
Zgodnie $\mathrm{z}$ zapisami art. 2 ust. 1 ustawy o działalności lobbingowej w procesie stanowienia prawa działalnością lobbingową jest każde działanie prowadzone metodami prawnie dozwolonymi, zmierzające do wywarcia wpływu na organy władzy publicznej $\mathrm{w}$ procesie stanowienia prawa. Nadrzędnym celem lobbingu jest uwzględnianie interesów określonych grup społecznych w rozstrzygnięciach podejmowanych przez organy władzy publicznej w zakresie procesu stanowienia prawa. Jak uważa Piotr Radziewicz, „Działalność lobbingowa może być wykonywana w celu osiągania zysku lub uzyskania innych korzyści materialnych. Polega ona wtedy na świadczeniu usług (na podstawie umowy), których przedmiotem jest reprezentowanie przed organami władzy publicznej lub $\mathrm{w}$ stosunkach $\mathrm{z}$ tymi organami interesów powierzonych przez inne podmioty (tzw. lobbing zawodowy). Działalność lobbingowa może być również realizowana w celu promowania lub obrony własnych interesów podmiotu lub interesów jego członków, w ramach ustalonego, stałego zakresu obowiązków przez członków lub pracowników tego podmiotu (tzw. lobbing etatowy)" ${ }^{26}$. Dlatego w procesie przebiegu postępowania, angażującego działalność lobbingową $\mathrm{w}$ wymiarze stanowienia prawa, istotne znaczenie ma tytułowa jawność wszelkich czynności, które podejmowane są przez organy władzy publicznej lub zawodowych lobbystów ${ }^{27}$. Konsekwencją tego kroku było zobowiązanie Rady Ministrów, zgodnie $z$ zapisami art. 3a ust. 2 ustawy o działalności lobbingowej w procesie stanowienia prawa, do przedstawiania Sejmowi, raz na 6 miesięcy roku kalendarzowego, wykazu projektów ustaw, co do których określono planowany termin ich przyjęcia przez Radę Ministrów.

Sam mechanizm przejrzystości i jawności procesu legislacyjnego jest zapewniony dzięki działaniom informacyjnym, które można odnaleźć w Regulaminie pracy Rady Ministrów ${ }^{28}$. Bardzo ważnym

${ }^{26}$ Zob. P. Radziewicz, O projekcie ustawy o działalności lobbingowej (druk sejmowy nr 2188), „Zeszyty Prawnicze Biura Studiów i Ekspertyz Kancelarii Sejmu” 2004, nr 1, s. 84.

27 A. Grochocińska, Jawność działalności lobbingowej $w$ procesie stanowienia prawa, „Acta Universitatis Wratislaviensis. Przegląd Prawa i Administracji” 2009, t. 80, nr 3127, s. 31.

28 Znowelizowana Uchwała nr 190 Rady Ministrów $z$ dnia 27 października 
elementem, wdrażanym przez Rządowe Centrum Legislacji, jest udostępnianie w Biuletynie Informacji Publicznej rządowych projektów dokumentów oraz innych dokumentów, które są ściśle powiązane $z$ ich procedowaniem ${ }^{29}$. Zgodnie $z \S 4$ powyższego Regulaminu, w zakresie i na zasadach określonych w niniejszej uchwale i przepisach odrębnych, projekty dokumentów rządowych, a także wszelkie dokumenty dotyczące prac nad tymi projektami udostępnia się w Biuletynie Informacji Publicznej. Natomiast na podstawie $\S 52$ ust. 1-3 Regulaminu, $z$ chwilą skierowania do uzgodnień, konsultacji publicznych lub opiniowania projektu założeń projektu ustawy, projektu ustawy lub projektu rozporządzenia, organ wnioskujący udostępnia projekt w Biuletynie Informacji Publicznej na stronie podmiotowej Rządowego Centrum Legislacji, w serwisie Rządowy Proces Legislacyjny (dalej: RPL). Jeżeli zaś projekt został skierowany do uzgodnień, konsultacji publicznych lub opiniowania, udostępnienie w RPL następuje $z$ chwilą wykonania pierwszej z tych czynności. Udostępnieniu w RPL podlegają również wszelkie dokumenty dotyczące prac nad projektem, w tym zgłoszenia zainteresowania pracami nad projektem, wniesione w trybie regulacji prawnych o działalności lobbingowej w procesie stanowienia prawa.

W odniesieniu do kreowania procesu legislacyjnego w polskim parlamencie przejrzystość, transparentność i jawność tworzenia prawa gwarantuje udostępnianie informacji w Systemie Informacyjnym Sejmu oraz w Biuletynie Informacji Publicznej Senatu ${ }^{30}$. Ciekawą sprawę w zakresie transparentności procesu stanowienia prawa prowadził w dniu 10 lutego 2014 r. Naczelny Sąd Administracyjny (NSA). Jedno ze stowarzyszeń skierowało do Trybunału Konstytucyjnego wniosek dotyczący udostępnienia informacji publicznej w zakresie nowych propozycji zmian ustawy o Trybunale Konstytucyjnym. Naczelny Sąd Administracyjny przy ocenie

2013 r. - Regulamin pracy Rady Ministrów (M.P. poz. 979 ze zm.).

29 Obowiązek ten wynika wprost z $\S 4$ i 552 ust. 1 Regulaminu pracy Rady Ministrów, dalej: Regulamin.

30 Zob. M. Bernaczyk, Obowiązek bezwnioskowego udostępniania informacji publicznej, Warszawa 2008, s. 162-163. 
wniosku dokonał oceny w kontekście jawności procesu stanowienia prawa $^{31}$. Wskazano bowiem, że wniosek skarżącego stowarzyszenia dotyczył konkretnego projektu zmian w ustawie, a więc w zasadzie udzielenia informacji o faktach będących w posiadaniu Prezesa Trybunału Konstytucyjnego na dzień złożenia wniosku. „[...] Ważne jest bowiem, w świetle zasady transparentności procesu legislacyjnego, aby już na tym etapie projektowania regulacji można było się zapoznać z merytorycznymi propozycjami zmian do ustawy, przygotowanymi przez sędziów Trybunału, i skonfrontować zakres ewentualnych rozbieżności pomiędzy propozycjami tych zmian a finalnym projektem ustawy złożonym przez Prezydenta w formie inicjatywy ustawodawczej" ${ }^{2}$. Analiza wyroku NSA wskazuje jednoznacznie, że jawność procesu tworzenia prawa nie może być ograniczana tylko i wyłącznie do jawności samego procesu legislacyjnego. Proces ten dotyczy również działalności organów publicznych, silnie powiązanych prawnie i funkcjonalnie $z$ tym procesem.

Obecne regulacje prawne, dotyczące Konstytucji Rzeczypospolitej Polskiej oraz ustawy o dostępie do informacji publicznej, dostarczają właściwych instrumentów do zdobywania wiedzy o procesach tworzenia prawa. Trzeba też zaznaczyć, że zasada jawności procesu legislacyjnego bardzo rzadko spotyka się z negatywnym nastawieniem i odbiorem społecznym. Nie budzi wątpliwości fakt, że dostęp do informacji publicznej, w zakresie planowanych zmian legislacyjnych, jest niezbędnym elementem prawidłowo funkcjonującego państwa prawa. Wynika to bezspornie $z$ treści preambuły ustawy zasadniczej, w której to Konstytucja Rzeczypospolitej Polskiej została wskazana „[...] jako prawa podstawowe dla państwa, oparte na poszanowaniu wolności i sprawiedliwości, współdziałaniu władz, dialogu społecznym oraz na zasadzie pomocniczości umacniającej uprawnienia obywateli i ich wspólnot [...]”33.

31 S. Osowski, B. Wilk, Jawność jako zasada demokratycznego państwa prawa, „Krajowa Rada Sądownictwa” 2016, nr 4, s. 29-31.

${ }^{32}$ Wyrok Naczelnego Sądu Administracyjnego z dnia 10 stycznia 2014 r., I OSK 2213/13, Lex nr 1424910.

33 Preambuła Konstytucji RP. 


\section{Zasada jawności w gospodarowaniu środkami publicznymi}

Niezwykle ważną zasadą w realizacji funduszy publicznych jest ich przedmiotowa jawność. Na podstawie art. 33 ust. 1 ustawy o finansach publicznych gospodarowanie środkami publicznymi jest jawne. Pojawia się również wyjątek, w którym zasady jawności nie stosuje się do środków publicznych, których pochodzenie lub przeznaczenie zostało uznane za informację niejawną na podstawie odrębnych przepisów lub jeżeli wynika to $z$ umów międzynarodowych $^{34}$.

Ustawodawca w sposób konkretny i szczegółowy w art. 34 ust. 1 ustawy o finansach publicznych określa sposób realizowania zasady jawności, która m.in. dotyczy:

- jawności debaty budżetowej w Sejmie i Senacie oraz debat budżetowych w organach stanowiących jednostek samorządu terytorialnego;

- jawności debaty nad sprawozdaniem $z$ wykonania budżetu państwa w Sejmie i debat nad sprawozdaniami $z$ wykonania budżetów jednostek samorządu terytorialnego;

- jawności debaty nad projektem uchwały w sprawie wieloletniej prognozy finansowej jednostki samorządu terytorialnego;

- podawania do publicznej wiadomości przez jednostki sektora finansów publicznych informacji dotyczących:

a) zakresu zadań lub usług wykonywanych lub świadczonych przez jednostkę oraz wysokości środków publicznych przekazanych na ich realizację,

b) zasad i warunków świadczenia usług dla podmiotów uprawnionych,

c) zasad odpłatności za świadczone usługi;

- zapewniania radnym danej jednostki samorządu terytorialnego dostępu do:

34 Art. 33 ust. 1-2 Ustawy z dnia 27 sierpnia 2009 r. o finansach publicznych (tekst jednolity: Dz.U. z 2021 r. poz. 305 ze zm.), dalej: u.f.p. 
364 Pawez Romaniuk

a) dowodów księgowych i dokumentów inwentaryzacyjnych,

b) informacji o wynikach przeprowadzonych kontroli gospodarki finansowej,

c) sprawozdania $z$ wykonania planu audytu za rok poprzedni;

- udostępniania przez jednostki sektora finansów publicznych wykazu podmiotów spoza sektora finansów publicznych, którym ze środków publicznych została udzielona dotacja, dofinansowanie realizacji zadania lub pożyczka;

- udostępniania corocznych sprawozdań, dotyczących finansów i działalności jednostek organizacyjnych, należących do sektora finansów publicznych;

- podejmowania, w głosowaniu jawnym i imiennym, uchwał organu wykonawczego jednostki samorządu terytorialnego, dotyczących gospodarowania środkami publicznymi;

- podawania do publicznej wiadomości treści planów działalności, sprawozdań $z$ wykonania planów działalności oraz oświadczeń o stanie kontroli zarządczej ${ }^{35}$.

W obszarze zainteresowań finansowych społeczeństwa najczęściej oczekiwanymi informacjami są informacje o szczegółowych wydatkach i konkretnych operacjach finansowych, które zawierane są przez podmioty publiczne. Dość problematycznym zagadnieniem prawnym wciąż pozostaje dostępność informacji publicznej o imionach i nazwiskach osób, będących np. partnerem samorządów terytorialnych. W tym zakresie niezwykle pomocny okazał się wyrok Sądu Najwyższego z dnia 8 listopada 2012 r., w którym Sąd zaznaczył, że udostępnienie informacji o imieniu i nazwisku partnera gminy, w przypadku umów, w żaden sposób nie narusza prywatności takiej osoby. Co więcej, Sąd zaznaczył, że osoba współpracująca $z$ gminą powinna mieć świadomość, że jej dane nie pozostaną anonimowe. Sąd zauważył również, że dla osoby, która występuje $z$ wnioskiem o udostępnienie informacji publicznej, dotyczącym zawierania przez gminy umów cywilnoprawnych, to właśnie

${ }^{35}$ Zob. art. 34 ust. 1 u.f.p. 
dane stron takich umów najczęściej są ważniejszym elementem niż sama ich treść ${ }^{36}$. Powyższy wyrok Sądu Najwyższego stał się ważnym punktem odniesienia w kontekście wyznaczenia szczelnej granicy między konstytucyjnym prawem do informacji publicznej, stanowiącym aspekt jawności, a prawną ochroną prywatności. Jest to tym bardziej doniosłe zagadnienie, że w nieodległej przyszłości przyjęte zostały regulacje prawne dotyczące prawa do ochrony osób fizycznych, znane wszystkim jako RODO ${ }^{37}$.

Wielokrotnie niejeden organ administracji publicznej spotkał się z problemem udostępnienia informacji publicznej, którego przedmiotem była sfera wynagrodzeń. Jeżeli wniosek o udostępnienie informacji publicznej dotyczy kwot przeznaczanych na wynagrodzenia, można spotkać się z doktryną sądów, że przekazanie takich danych co do zasady nie narusza prywatności osób fizycznych ${ }^{38}$. W sytuacji, kiedy wniosek taki dotyczy natomiast wynagrodzenia konkretnych osób, sądy zazwyczaj pozostają na stanowisku, że udostępnienie informacji o wynagrodzeniach osób niepełniących funkcji publicznych narusza ich prawo do prywatności, a prawo do informacji publicznej w takich sytuacjach podlega uzasadnionym ograniczeniom. Ustawodawca wypowiada się w tej materii w art. 5 ust. 2 zdanie 2 ustawy o dostępie do informacji publicznej, według którego ograniczenie takie nie dotyczy informacji o osobach pełniących funkcje publiczne, mających związek $z$ pełnieniem tych funkcji, w tym o warunkach powierzenia i wykonywania funkcji, oraz przypadku, gdy osoba fizyczna lub przedsiębiorca rezygnują z przysługującego im prawa ${ }^{39}$. Zatem prawo dostępu do informacji publicznej w zakresie dostępu do wiedzy o wynagradzaniu w sferze publicznej oprócz argumentu społecznego, że stanowi część wiedzy

\footnotetext{
36 Wyrok SN z dnia 8 listopada 2012 r., I CSK 190/12, Lex nr 1283743.

37 Rozporządzenie Parlamentu Europejskiego i Rady (UE) 2016/679 z dnia 27 kwietnia 2016 r. w sprawie ochrony osób fizycznych w związku z przetwarzaniem danych osobowych i w sprawie swobodnego przepływu takich danych oraz uchylenia dyrektywy 95/46/WE.

38 Przykład wyroku NSA z dnia 18 lutego 2015 r., I OSK 695/14, Lex nr 1657860.

39 Zob art. 5 ust. 2 zdanie 2 u.d.i.p.
} 
o publicznych wydatkach, ma również ważne znaczenie dla dokonywanej wielokrotnie oceny $\mathrm{np}$. dysproporcji płacowych.

\section{Wnioski}

Jedną $\mathrm{z}$ ważniejszych przesłanek funkcjonowania administracji publicznej jest jawność sfery publicznej czy szeroko rozumianej administracji publicznej. Organy administracji publicznej mają prawny obowiązek przedstawiania informacji publicznej nie tylko w Biuletynie Informacji Publicznej oraz Centralnym Repozytorium Informacji Publicznej, lecz także na żądanie zainteresowanego konkretną sprawą. Obywatele mają prawo do rzetelnej informacji publicznej, w tym uzyskania informacji przetworzonej w takim zakresie, w jakim jest to szczególnie ważne dla interesu publicznego. Mają też prawo wglądu do dokumentów urzędowych czy dostępu do posiedzeń kolegialnych organów władzy publicznej, pochodzących z powszechnych wyborów.

Oczywiście w praktyce zasada jawności nie zawsze jest respektowana i dochodzi do naruszeń praw i swobód obywatelskich. Jednak uwzględniając aspekt społeczny, w wyniku którego każdy obywatel na mocy przyznanego mu prawa do informacji publicznej staje się aktywnym uczestnikiem życia publicznego, należy bezwzględnie przestrzegać istniejących przepisów prawnych i wdrażać je. Stąd niezwykle uniwersalną przesłanką staje się budowanie świadomości społecznej na temat transparentności życia publicznego, trwale usytuowanej w Konstytucji Rzeczypospolitej Polskiej w zakresie respektowania zasady jawności, przejawiającej się prawem dostępu do rzetelnej i ogólnodostępnej informacji publicznej. 


\section{STRESZCZENIE}

Wybrane prawnoadministracyjne aspekty realizacji zasady jawności w sferze funkcjonowania administracji publicznej

Przedmiotowa zasada jawności w sferze aktywności administracji publicznej, a także jawność informacji na temat funkcjonowania państwa i reprezentujących je funkcjonariuszy publicznych są jednymi $z$ fundamentalnych kryteriów rozwoju każdego demokratycznego państwa prawa. Jawność, jako dobro wspólne, musi być identyfikowana jako konsekwencja wiernej służby wszelkich organów i instytucji publicznych oraz reprezentujących je funkcjonariuszy publicznych. Wszyscy powinni być zainteresowani tym, aby państwo prawa funkcjonowało praworządnie, szanując przyjęte wolności i prawa wszystkich, którzy znajdują się pod jego władzą, korzystając jednocześnie $z$ prawa dostępu do informacji publicznej.

Słowa kluczowe: administracja publiczna; zasada jawności; informacja publiczna; przejrzystość; stanowienie prawa; finanse publiczne

\section{SUMMARY}

Selected legal and administrative aspects of implementing the principles of openness in the public administration

The subject activity of openness in the sphere of public activity, as well as openness of information on state affairs and representing current clients, is one of the fundamental issues in the development of every democratic state. Openness, as a public good, must be identified as the corollary of the faithful service of all organs and institutions and the service that represents them. Everyone should be interested in the rule of law for the rule of law, respecting the freedom and right of all under its authority to access the right of access to information.

Keywords: public administration; the principle of openness; public information; transparency; lawmaking; public finance 
368 Pawet Romaniuk

\section{BIBLIOGRAFIA}

Banaszak B., Prawo konstytucyjne, Warszawa 2008.

Bernaczyk M., Obowiazek bezwnioskowego udostępniania informacji publicznej, Warszawa 2008.

Bernaczyk M., Konstytucyjne prawo do informacji o działalności posłów i senatorów a zakres podmiotowy ustawy o dostępie do informacji publicznej, „Przegląd Sejmowy” 2012, nr 3.

Górzyńska T., Zasada jawności w administracji, „Państwo i Prawo” 1998, nr 6.

Grochocińska A., Jawność działalności lobbingowej $w$ procesie stanowienia prawa, „Acta Universitatis Wratislaviensis. Przegląd Prawa i Administracji” 2009, t. 80, nr 3127.

Gulczyński M., Zasada zwierzchnictwa narodu, w: Zasady podstawowe polskiej Konstytucji, red. W. Sokolewicz, Warszawa 1998.

Jabłoński M., Udostępnienie informacji publicznej $w$ formie wglądu do dokumentu, Wrocław 2013.

Kraluk W., O rozumieniu i regulacji normatywnej demokracji bezpośredniej w nowej Konstytucji, „Gdańskie Studia Prawnicze” 1998, nr 3.

Mucha M., Obowiazki administracji publicznej w sferze dostępu do informacji, Wrocław 2002.

Osowski S., Wilk B., Jawność jako zasada demokratycznego państwa prawa, „Krajowa Rada Sądownictwa” 2016, nr 4.

Osowski S., Wilk B., Jawność jako wyznacznik legitymizacji władz publicznych, w: Studia nad współczesnymi ruchami społecznymi, red. A. Wojtaszak, Szczecin 2014.

Radziewicz P., O projekcie ustawy o działalności lobbingowej (druk sejmowy nr 2188), „Zeszyty Prawnicze Biura Studiów i Ekspertyz Kancelarii Sejmu” 2004, nr 1.

Sadomski J., w: Konstytucja RP, t. 1: Komentarz do art. 1-86, red. M. Safjan, L. Bosek, Warszawa 2016, Legalis.

Surówka A., Prawo dostępu do informacji publicznej $w$ orzecznictwie sądów administracyjnych, „Przegląd Prawa Konstytucyjnego” 2013, nr 3. 